Gut, 1973, 14, 133-138

\title{
Mobilization of tissue kallikrein in inflammatory disease of the colon
}

\author{
I. J. ZEITLIN' AND A. N. SMITH
}

From the Wolfson Laboratories, Gastrointestinal Unit, Western General Hospital, and the Department of Clinical Surgery, University of Edinburgh

SUMMARY Colonic tissue was taken at operation from 10 patients with active ulcerative colitis and three patients with uncomplicated diverticular disease but with severe symptoms. Levels of kininogen, kallikrein, and kallikrein precursor were measured in blood-free tissue samples. In normal colon tissue a kininogen occurred in the muscle and none was detected in the mucosa. Kallikrein and its precursor were found in mucosa but not in muscle. In acutely inflamed tissue from ulcerative colitis patients relatively high levels of active kallikrein were detected in the underlying colonic muscle. There was little change in the level of kallikrein in inflamed mucosa or of kininogen in the muscle of these patients. No kallikrein was found in colonic muscle from patients with diverticular disease and the mucosal kallikrein level in these patients was unchanged. The findings suggest a mechanism for the formation of kinins in the wall of the colon which is present in ulcerative colitis but not in diverticular disease.

Recent studies have shown that the gut wall contains a kinin-forming enzyme which is stored as an inactive precursor and which can be found in the mucosa at every level of the gut (Zeitlin, 1970, 1971, and 1972; Seki, Nakajima, and Erdös, 1972).

Kinins are considered to be likely mediators of the inflammatory reaction (Lewis, 1963). They are potent vasodilators, enhance capillary permeability, produce pain, and their destruction is inhibited at a slightly acid $p \mathrm{H}$, such as occurs in inflamed tissue. In the gut, kinins contract most longitudinal muscle while inhibiting circular muscle (Elliott, Horton, and Lewis, 1960; Fishlock, 1966). The presence, therefore, of a kinin-forming enzyme in the gut tissue makes it clearly of importance to determine whether this enzyme plays a role in inflammatory diseases of the gut, particularly where motility disorders are also present.

Free kinins, once they are formed, are rapidly destroyed by peptidases occurring in the blood and tissues. However, owing to their great potency, marked local effects can be caused by the occurrence of free kinin within tissue in quantities too minute

'Present address: Department of Pharmacology, University of Strathclyde, Glasgow G1 1XW.

Received for publication 5 December 1972. to produce any detectable systemic changes. Their labile nature makes it impractical to look for free kinins in the gut tissue in clinical situations. In the present study, levels of relatively stable kininforming enzyme have been determined in colonic tissue from patients with ulcerative colitis or diverticular disease.

\section{Preparation of Tissue}

\section{METHODS}

Tissue was obtained from patients who were having operations for acutely active ulcerative colitis and for uncomplicated diverticular disease but with severe symptoms. In the ulcerative colitis group the operation was a proctocolectomy so that tissue was obtained from several segments of the colon. In diverticular disease the operation was more restricted (partial left hemicolectomy). In the colitis group the tissue was obtained from patients who mainly had the left and distal colon affected with minimal involvement of the proximal, ie, right colon. A main vessel was cannulated for perfusion of a diseased and a normal segment of bowel (mainly left and right colon respectively). In diverticular disease the operation specimen contained mainly the sigmoid colon with or without part of the left colon. The bowel was perfused via the sigmoid and left 
colic artery and diseased tissue excised from the sigmoid colon and normal tissue from the upper (left or descending colon) end. The perfusions were performed as soon as possible after the operative excision with heparinized (10 units/ml) KrebsHenseleit solution at $37^{\circ} \mathrm{C}$ to flush out blood. If the solution was too cold, vasoconstriction prevented adequate removal of blood. With care it was possible to produce small areas of blood-free tissue which could be cut out. The tissue samples were then further washed in Krebs-Henseleit and stored in this solution at $4^{\circ} \mathrm{C}$ for up to one hour until transport to the laboratory for kininogen or kallikrein assay.

In the initial studies whole-thickness tissue was taken for kininogen estimation. In subsequent studies, the mucosal layer was dissected away from the muscle and the two tissues were assayed separately for kallikrein or kininogen content.

\section{KININOGEN ASSAY}

The tissue was washed in fresh Krebs-Henseleit solution, dried by briefly blotting with filter paper, and weighed. The available tissue per sample was usually about $0.5 \mathrm{~g}$. The tissue was homogenized in $80 \%$ ethanol (about $10 \mathrm{ml} / \mathrm{g}$ ) in a ground glass homogenizer. The ethanolic suspension was placed on a boiling water bath for 10 minutes to inactivate enzymes and to ensure kininogen precipitation. The homogenate was centrifuged to remove the ethanol and the precipitate was washed twice with distilled water and resuspended in distilled water. Aliquots of freshly shaken suspension were incubated with trypsin as described by Brocklehurst and Zeitlin (1967) to activate kininogen. The released kinin was compared with standard synthetic bradykinin (Sandoz) using the isolated oestrous rat uterus.

The unit of kininogen referred to in the text is the amount of kininogen releasing the equivalent of $1 \mu \mathrm{g}$ of synthetic bradykinin when treated as described.

\section{KALLIKREIN ASSAY}

The tissue was washed in fresh Krebs-Henseleit solution, dried by briefly blotting with filter paper, and weighed. The weight of tissue in each sample was usually about $0 \cdot 1-0.5 \mathrm{~g}$. The tissue was homogenized in exactly $10 \mathrm{ml}$ of fresh distilled water per gram, using a chilled ground-glass homogenizer. The homogenate was tested for unsatisfactory blood removal using Hemastix which has a detection limit of $30 \mu \mathrm{g}$ haemoglobin per litre. Samples were then allowed to incubate under toluene for 20 hours at $20^{\circ} \mathrm{C}$ to allow activation of the kallikrein. The homogenates were centrifuged to remove cell debris (about $2000 \mathrm{~g}$ ). To determine the kinin-forming activity of the supernatant, aliquots were incubated for 15 minutes at $37^{\circ} \mathrm{C}$ with excess of the stable substrate of Amundsen, Nustad, and Waaler (1963) in Krebs-Henseleit solution at $p \mathrm{H} \mathrm{8.0.} \mathrm{Orthophenan-}$ throline $(0.001 \mathrm{M})$ was present to inhibit kininase. The enzymic action was stopped by heating on a boiling water bath $(10 \mathrm{~min})$, and the incubates were rapidly frozen for storage. Extract and substrate incubated separately were included as controls. The released kinin was compared with standard synthetic bradykinin (Sandoz) using the isolated oestrous rat uterus. Where enzyme inhibitor studies were to be carried out, the extract was preincubated with inhibitor for $10 \mathrm{~min}$ before the addition of substrate.

The unit of kallikrein referred to in the text is the amount of kallikrein releasing the equivalent of $1 \mu \mathrm{g}$ of synthetic bradykinin in 15 minutes when incubated as described.

BIOASSAY

Routine kinin assays were carried out using the atropinized isolated oestrous rat uterus (Brocklehurst and Zeitlin, 1967). With some samples, a parallel bioassay was carried out using both isolated rat uterus and the isolated rat duodenum (Gaddum and Horton, 1959) in the presence of atropine sulphate $(1 \mu \mathrm{g} / \mathrm{ml})$ and 2-bromolysergic acid diethylamide (BOL-148, Sandoz) $(0.5 \mu \mathrm{g} / \mathrm{ml})$. Only kinins are known to contract the isolated rat uterus and relax rat duodenum under these conditions.

\section{STATISTICS}

The Wilcoxon matched pairs signed-ranks test was used to test differences for statistical significance.

\section{Results}

TISSUE KININOGEN IN ULCERATIVE COLITIS Blood-free gut wall contains a kinin precursor which may be activated by incubation with trypsin. The kininogen content was estimated in diseased wholethickness tissue taken from five patients with colitis. The level was found to be significantly raised $(P<0.05)$ when compared with a control sample of an adjacent area of 'normal' tissue (Fig. 1).

DISTRIBUTION OF COLON TISSUE KININOGEN AND KININ-FORMING ENZYME IN ULCERATIVE COLITIS

An increase in kininogen level can indicate a variation in production or consumption of kininogen. If the kininogen were not uniformly distributed through the gut wall, a loss of one of its compcnents, such as the mucosa in ulcerative colitis, could produce an apparent increase in tissue kininogen content. In a further series of five patients, the mucosa was separated from the colonic muscle. In two of these patients sufficient blood-free tissue was obtained to 
KININOGEN CONTENT

$\mu g$. Brady. Equiv./gm. tissue wet wt.

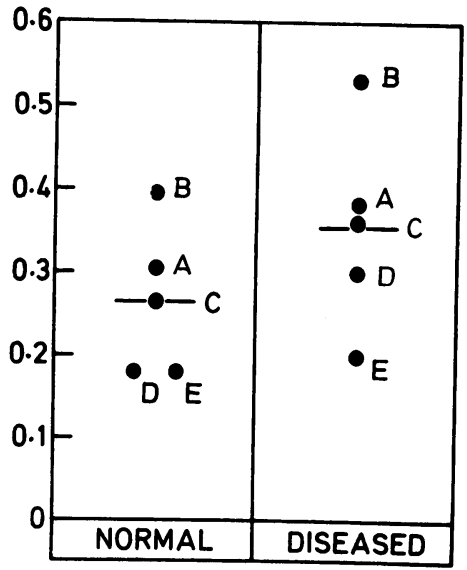

Fig. 1 Kinin precursor levels measured in normal and adjacent diseased full-thickness colon wall from five patients with ulcerative colitis.

KININ-FORMING ACTIVITY

$\mu \mathrm{g}$. Brady. Equiv./15 min./gm. tissue

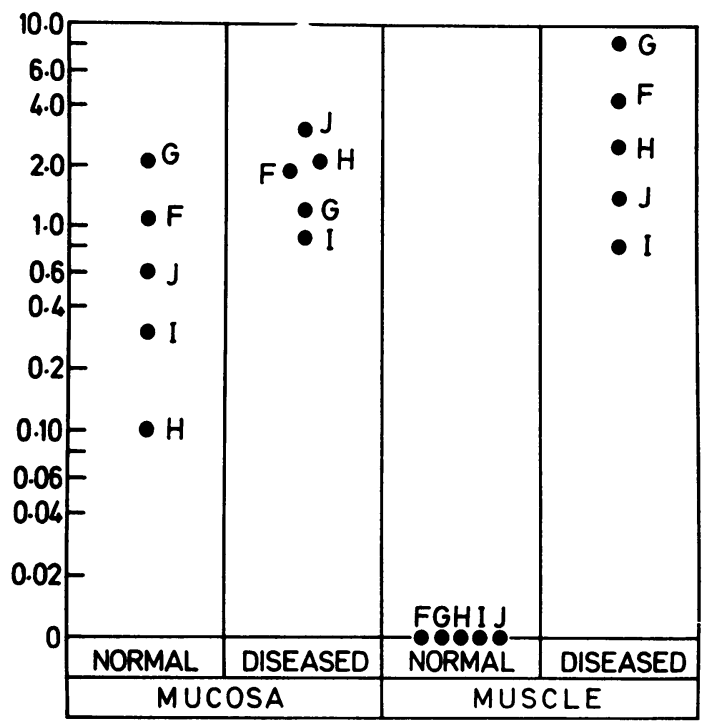

Fig. 2 Total kinin-forming enzyme in colonic tissue from five patients with ulcerative colitis. Tissue was taken from diseased and adjacent normal segments of colon. The values are plotted on a logarithmic scale.

assay both kinin-forming enzyme and kininogen simultaneously in both types of tissue. In the remaining patients only the enzyme was assayed.

It was found that kininogen was present only in the muscular tissue (Table), while none could be detected in mucosa. Furthermore, with the mucosa removed, there was very little difference in kininogen level between the normal and diseased portions of tissue.

\begin{tabular}{lllll}
\hline Patient & & $\begin{array}{l}\text { Kininogen } \\
\text { (Units/g } \\
\text { tissue) }\end{array}$ & $\begin{array}{l}\text { Kallikrein } \\
\text { (Units/g } \\
\text { tissue) }\end{array}$ \\
\hline 1 & Normal & $\begin{array}{l}\text { Muscle } \\
\text { Mucosa }\end{array}$ & $\begin{array}{l}0.51 \\
0\end{array}$ & 0 \\
& Diseased & Muscle & $0 \cdot 49$ & $1 \cdot 1$ \\
& & Mucosa & 0 & $4 \cdot 3$ \\
& Normal & Muscle & 0.53 & $1 \cdot 9$ \\
& Mucosa & 0 & 0 \\
& Diseased & Muscle & 0.55 & $2 \cdot 1$ \\
& & Mucosa & 0 & $1 \cdot 1$ \\
& & & $1 \cdot 2$ \\
\hline
\end{tabular}

Table The distribution of kallikrein and kininogen in normal and diseased colonic tissue from two patients with ulcerative colitis

The kinin-forming activity was also not continuously distributed throughout the colon wall. In the normal tissue, the kinin-forming enzyme was present only in the mucosa (mean $=0.84$ Units $/ g$ ) while none could be detected in the colonic muscle (mean $<0.02$ Units/g) (Table and Fig. 2). However, in the diseased segment, considerable kinin-forming activity could be detected in every case in the muscular tissue (mean $=3.4$ Units/g) (Fig. 2), the values ranging from more than two to 25 times that found in the normal mucosa. When the enzyme levels in diseased and normal muscle were compared, the increase from zero occurred more often than could be accounted for by random variation $(P=0.05)$. The level of enzyme in the diseased mucosae (mean 1.8 Units/g) had increased when compared to the mean normal mucosa level but this was not statistically significant $(P>0.05)$; however it may be relevant that in colitis the mucosal layer is being destroyed and there may have been therefore an unmeasured loss into the bowel lumen.

In two patients, kinin-forming activity was estimated immediately on receipt of the tissue samples in the laboratory, and then following autolytic activation (see Methods). The results indicated that the enzyme present in the diseased muscle was entirely in the active state, while some $50 \%$ of the mucosal enzyme was in the active state. However, whether this represented the state of activation of the enzyme in vivo could not be satisfactorily determined, since activation during surgical manipulation and the necessary delay between excision and assay could not be excluded. 
LEVELS OF KININ-FORMING ENZYME IN COLONIC TISSUE IN DIVERTICULAR DISEASE Uncomplicated diverticular disease is considered nowadays to be a condition of the large bowel in which a disorder of its musculature is initially a more important feature than inflammation. Tissue was examined from patients with this condition in order to see whether kallikrein occurred in colonic muscle in an uninflamed condition, for example, secondary to motor changes, and also to provide an additional control for the colitis study. In the colitis group, diseased tissue from the left colon was being compared with normal tissue from the right colon and the changes found could have been due to regional variation. The diverticular disease specimens were samples from normal and diseased tissue in the left colon; the normal samples would act as the controls for diverticular disease but would act as a further

KININ-FORMING ACTIVITY

$\mu \mathrm{g}$. Brady. Equiv./15 min./gm. tissue

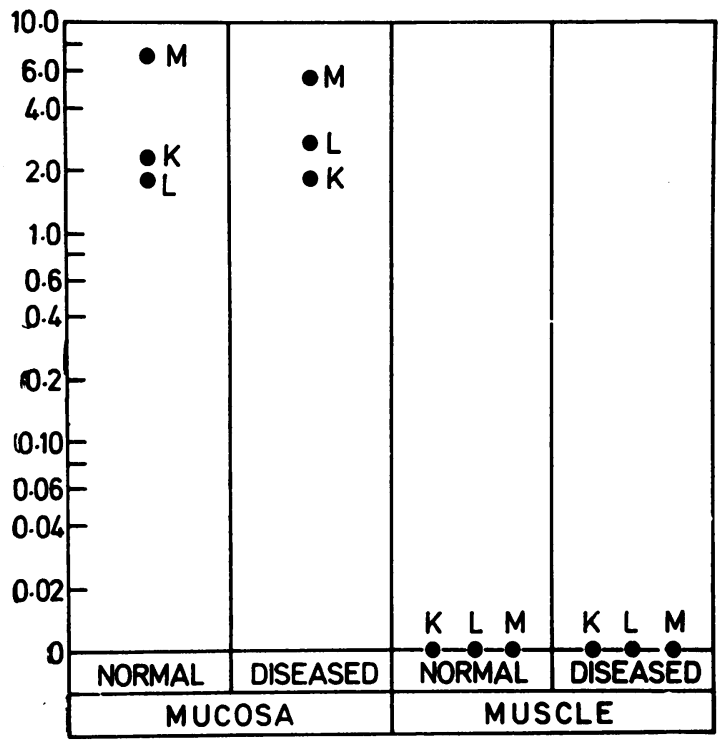

Fig. 3 Total kinin-forming enzyme in colonic tissue from three patients with diverticular disease. Samples were taken from diseased and normal colonic tissue nearby. The values are plotted on a logarithmic scale.

control for the colitis cases since they were from the same colonic site of origin. In patients with diverticular disease no kinin-forming enzyme could be detected in either normal or diseased muscle (Fig. 3).

CHARACTERIZATION OF ENZYMIC ACTIVITY It was necessary to determine whether the activity appearing in the diseased muscle tissue from ulcerative colitis patients was indeed a kinin-forming enzyme and also to show that it was not merely the result of contamination with trypsin or plasma kallikrein.

Enzyme-containing extract from the diseased muscle of two ulcerative colitis patients was pooled. Incubations were carried out as described for the kallikrein assay. When extract or human plasma substrate were incubated separately, no smoothmuscle stimulant activity was formed (Fig. 4). When extract and substrate were incubated together, activity appeared in the incubate which contracted the rat uterus and relaxed rat duodenum in the presence of atropine and 2-bromolysergic acid diethylamine, a 5-HT antagonist (Fig. 4). The extract thus contained an enzyme which released plasma kinin-like activity (see Methods). This kinin-forming enzyme was almost completely inhibited $(96.8 \%)$ by Trasylol (100 Units/ml) but only slightly inhibited $(4.5 \%)$ by soybean trypsin inhibition $(100 \mu \mathrm{g} / \mathrm{ml})$ A similar response to these inhibitors was shown by the kininforming enzyme present in the normal mucosa. The enzyme thus differed from trypsin and plasma kallikrein which are inhibited by both inhibitors, It should be noted in this respect, however, that Seki

TEST INCUBATES

STANDARD BRAOUKININING)

Rat uterus

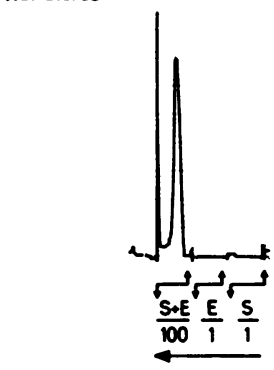

Rat duodenum

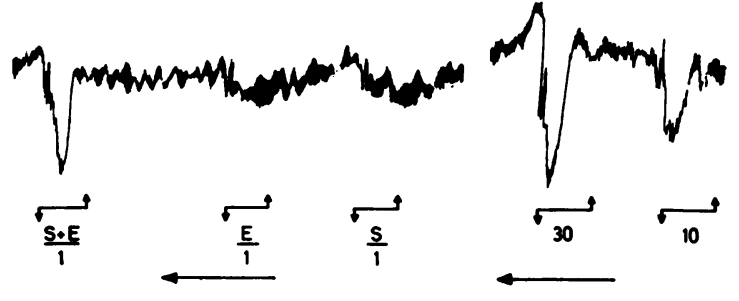

Fig. 4 Parallel bioassay on rat uterus and rat duodenum, of activity formed when activated extract $(\mathrm{E})$ of diseased colonic muscle from ulcerative colitis patients is incubated with kinin-forming substrate (S). All doses added $0.1 \mathrm{ml}$.; dilutions shown in figure. Contact time one minute for the rat uterus (drum stopped between doses), two minutes for the rat duodenum (drum run continuously). 
et al (1972) report that purified human colonic enzyme is partially inhibited $(47 \%)$ by the soybean inhibitor. The kinin-forming activity was not distinguished from human pancreatic kallikrein by these tests. However, the fact that the activity was not continuously distributed through the gut wall and could not be detected in normal colonic muscle was a reasonable indication that the measurable activity was not merely the result of contamination from gut contents, blood, or lymph.

\section{Discussion}

There have been few studies on intrinsic kininforming activity in the wall of the alimentary tract. Twelve years ago, Werle and his colleagues (1960) reported that a hypotensive substance can be liberated from human and animal gut wall by incubation with trypsin. Homogenates of intestinal mucosal cells from rats and rabbits were subsequently shown to contain kinin-forming activity (Amundsen and Nustad, 1965; Burger, Lembeck, and Wagner, 1968). The kinin-forming enzyme of the rat gut wall occurs as an inactive precursor and has properties similar to some glandular kallikreins (Zeitlin, 1971 and 1972). Recently Erdös and his colleagues (Seki et al, 1972) have purified kallikrein from normal human, monkey, and dog colonic mucosae. These workers found that the purified human enzyme behaved more like plasma kallikrein than a glandular kallikrein. No previous studies have related intestinal kinin-forming enzyme or its precursor to the aetiology of human alimentary disease, nor has the presence of a kininogen in human gut wall been previously reported.

In the present investigation it was found that the human colon wall contained both a kinin-forming enzyme and a kininogen. In normal tissue, the kininforming enzyme and its precursor were present only in the mucosa while the kininogen occurred only in the muscle. When diseased tissue was compared with adjacent relatively normal tissue from patients with ulcerative colitis, it was found that while no kininforming enzyme or its precursor was present in normal muscle, considerable quantities of active enzyme could be detected in the diseased muscle. The enzymic activity found in both normal mucosa and diseased mucosa and muscle was distinguished from trypsin and plasma kallikrein and was not due to contamination from these sources. No similar infiltration of kinin-forming enzyme into the muscular tissue was found to occur in patients with diverticular disease of the colon.

Studies with isolated strips of human taenia coli have shown that this muscle has a complex response to contact with bradykinin. Taenia coli strips from some donors give a biphasic response with relax- ation at low doses and contraction at higher doses of bradykinin (Fishlock, 1966) while strips from other donors react only with contraction to as little as $10 \mathrm{ng} / \mathrm{ml}$ (Fishlock, 1966; Zeitlin and Smith, 1971). Circular muscle strips from the human colon respond only with relaxation to bradykinin (threshold = $5 \mathrm{ng} / \mathrm{ml}$ ) (Fishlock, 1966). In situ, human colonic motility is inhibited by intravenous infusion of bradykinin (Murrell and Deller, 1967).

Ulcerative colitis is a disease of the colonic and rectal mucosa and the inflammation does not generally extend beyond the submucosal layer, yet abnormalities in the smooth muscle of the bowel and disordered motility are characteristic of the disease. Colonic motility is generally reduced in patients with ulcerative colitis (Spriggs, Code, Bargen, Curtiss, and Hightower, 1951 ; Kern, Almy, Abbot, and Bogdonoff, 1951; Bloom, LoPresti, and Farrar, 1968; Jalan, Walker, Prescott, Butterworth, Smith, and Sircus, 1970), while notable features of the condition (Lennard-Jones, Lockhart-Mummery, and Morson, 1968), are the striking shortening of the colon with loss of the haustra which are normally maintained in part by an action of the circular muscle of the colon, which also becomes thickened. The smooth $x$-ray appearance of the colonic wall at barium enema examination has been explained on this basis, but no biochemical differences have hitherto been demonstrated between diseased and normal muscle which satisfactorily explain these changes. It has now been shown that the diseased muscle differs from healthy muscle in containing active kinin-forming enzyme; it also contains a kininogen, as does the normal muscle. Although the kininogen level in the diseased muscle is not decreased, it has previously been noted in carcinoid patients that while transitory kinin release results in a fall in plasma kininogen levels, chronic over-production of kinin may be accompanied by abnormally high kininogen levels (Zeitlin and Smith, 1970). The release of kinins within diseased colonic muscle would reasonably explain the shortening of the colon and the inhibition of motility seen in ulcerative colitis.

It is not difficult to imagine a mechanism by which the enzyme protein may pass from the mucosa into the muscle tissue. In the severely inflamed mucosae of ulcerative colitis, the abnormal release of permeability increasing factors such as 5-HT, histamine, or even excessive activation of mucosal kinin formation could permit the enzyme protein to pass through cellular membranes adjacent to the inflammation. Some could pass into the muscle tissue, the remainder would be flushed away by the blood. Although in terms of local tissue concentration the amounts of enzyme involved are large, in terms of whole body physiology, the total amount of active 
enzyme is small. The chronic leakage of minute amounts of the enzyme into the circulation is unlikely to produce any marked systemic vasomotor changes. If the formation of kinins represents part of an inflammatory reaction in the wall of the colon in ulcerative colitis, by these pharmacological criteria diverticular disease is affected by a dissimilar type of process.

This work was supported by a Medical Research Council temporary research grant to $\mathrm{Dr} \mathrm{W}$. Sircus and by S.H.E.R.T. grant no. 291 to A. N. Smith.

\section{References}

Amundsen, E., and Nustad, K. (1965). Kinin-forming and destroying activities of cell homogenates. J. Physiol. (Lond.). 179, 479-488.

Amundsen, E., Nustad, K., and Waaler, B. (1963). A stable substrate for the assay of plasma kinin-forming enzymes. Brit.J. Pharmacol., 21, 500-508.

Bloom, A. A., LoPresti, P., and Farrar, J. T. (1968). Motility of the intact human colon. Gastroenterology, 54, 232-240.

Brocklehurst, W. E., and Zeitlin, I. J. (1967). Determination of plasma kinin and kininogen levels in man. J. Physiol. (Lond.), 191, 417-426.

Burger, A., Lembeck, F., and Wagner, J. (1968). Serotonin und Kininogenase-Aktivităt in Fraktionen der Dünndarmschleimhaut des Kaninchens. Naunyn-Schmiedeberg's Arch. Pharmak. exp. Path., 261, 412-421.

Elliott, D. F., Horton, E. W., and Lewis, G. P. (1960). Actions of pure bradykinin. J. Physiol. (Lond.), 153, 473-480.

Fishlock, D. J. (1966). Effect of bradykinin on the human isolated small and large intestine. Nature (Lond.), 212, 1533-1535.

Gaddum, J. H., and Horton, E. W. (1959). The extraction of human urinary kinin (substance $Z$ ) and its relation to the plasma kinins. Brit. J. Pharmacol., 14, 117-124.
Jalan, K. N., Walker, R. J., Prescott, R. J., Butterworth, S. T. G., Smith, A. N., and Sircus, [W. (1970). Faecal stasis and diverticular disease in ulcerative colitis. Gut, 11 .688-696.

Kern, F., Jr., Almy, T. P., Abbot, F. K., and Bogdonoff, M. D.(1951). The motility of the distal colon in non-specific ulcerative colitis. Gastroenterology, 19, 492-503.

Lennard-Jones, J. E., Lockhart-Mummery, H. E., and Morson, B. C. (1968). Clinical and pathological differentiation of Crohn's disease and proctocolitis. Gastroenterology, 54, 1162-1170.

Lewis, G. P. (1963). Pharmacological actions of bradykinin and its role in physiologocal and pathological reactions. Ann. N.Y. Acad. Sci., 104, 236-249.

Murrell, T. G. C., and Deller, D. J. (1967). Intestinal motility in man: the effect of bradykinin on the motility of the distal colon. Amer. J. dig. Dis., n.s., 12, 568-576.

Seki, T., Nakajima, T., and Erdös, E. G. (1972). Colon kallikrein, its relation to the plasma enzyme. Biochem. Pharmacol., 21, 1227-1236.

Spriggs, E. A., Code, C. F., Bargen, J. A., Curtiss, R. K., and Hightower, N. C., Jr. (1951). Motility of the pelvic colon and rectum of normal persons and patients with ulcerative colitis. Gastroenterology, 19, 480-491.

Werle, E. (1960). Kallikrein, kallidin, and related substances. In Polypeptides which Affect Smooth Muscles and Blood Vessels, edited by M. Schachter, pp. 199-209. Pergamon Press, Oxford.

Zeitlin, I. J. (1970). Kinin release associated with the gastro-intestinal tract. In Bradykinin and Related Kinins, edited by F. Sicuteri, M. Rocha e Silva, and N. Back, pp. 329-339. Plenum Press, New York.

Zeitlin, I. J. (1972). Pharmacological characterization of kininforming activity in rat intestinal tissue. Brit. J. Pharmacol., 42, 648-649.

Zeitlin. I. J. (1972). Rat intestinal kallikrein. In Vasoactive Peptides, edited by N. Back and F. Sicuteri, pp. 289-296. New York.

Zeitlin, I. J., and Smith, A. N.(1970). Kinin assays in clinical conditions. R. Gastroent., 2, 176-181.

Zeitlin, I. J., and Smith, A. N. (1971). Hormonal factors stimulating the motility of the intestinal tract in inflammation of its wall. Amer. J. dig. Dis., 16. 553-555. 